\title{
DNA Minor Groove Binding Agent SG2000
}

National Cancer Institute

\section{Source}

National Cancer Institute. DNA Minor Groove Binding Agent SG2000. NCI Thesaurus.

Code C29435.

A sequence-selective pyrrolobenzodiazepine (PBD) dimer with potential antineoplastic activity. Following intravenous administration, DNA minor groove binding agent SG2000 preferentially and covalently binds to purine-GATC-pyrimidine sequences, with the imine/carbinolamine moieties of SG2000 binding to the N2 positions of guanines on opposite strands of DNA. This induces interstrand cross-links and inhibits both DNA replication and gene transcription, which lead to the inhibition of cell growth. With a preference for binding to purine-GATC-pyrimidine sequences, SG2000 adducts do not appear to be susceptible to p53-mediated DNA excision repair. 